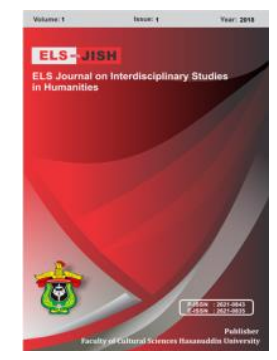

ELS-JISH

ELS Journal on Interdisciplinary Studies on Humanities

Volume 1 Issue 1, 2018

ISSN (print) : 2621-0843

ISSN (online) : 2621-0835

Homepage : http://journal.unhas.ac.id/index.php/jish

\title{
The Politeness Strategies of Negation Used by English and Buginese
}

\author{
Najmiah Daud ${ }^{1 *}$, Abdul Hakim Yassi ${ }^{2}$, Sukmawaty ${ }^{3}$ \\ *E-mail of Corresponding Author: najmiah.daud@yahoo.com
}

\begin{abstract}
A good communication is a cooperate communication, but when someone wants to deny someone or something, it can be FTA (Face Threatening Acts) in some situations, so she/he needs to express it in polite way to save the face of each through the use of the politeness strategies. This research is aimed to investigate (1) the politeness strategies used by Buginese and American people in using the negation expression; (2) the influence of social and cultural relationship on the politeness strategies used by the Buginese and American people when using negation expression. This was a comparative study between Buginese and English language in using negation. The research used the qualitative descriptive approach. English and Buginese data were obtained through DCT, questionnaire. The research result indicates that three politeness strategies are used by American and Buginese people in using negation namely: the bald on record, positive politeness, and negative politeness. The American people tend to use those strategies in polite way to negate something by being more friendly and using the casual language with other people. On the other hand, Buginese people tend to use formal language as the politeness strategies in making negation. The significant differences between both languages can be seen from the indirect and direct strategies in making negation. English tends to use direct strategies, while Buginese tends to apply indirect negation. The research also indicates that the other aspects influencing the politeness strategies used are; gender, social situation, social distance or intimacy, social status, relationship between interlocutors. Buginese people indicate the politeness by giving the formal treatment because they are more hierarchical and pay more attention to use honorific address term and politeness marker such as iye'. On the other case, American people are more friendly and emphasize the solidarity.
\end{abstract}

Keywords: Politeness Strategies, Negation, Face Threatening Acts.

How to cite: Daud, N., et al. (2018). The Politeness Strategies of Negation Used By English and Buginese. ELS-Journal on Interdisciplinary Studies in Humanities, 1 (I), 1-12.

\section{Introduction}

People use language to convey their message or feeling. Sometimes people us formal, semiformal and also non formal. Chaer and Agustina (2010), reveal that the degree of formality of language depends on the social situation and many aspects on that language. It cannot be separated but it changeable. A good interaction between interlocutors can be determined by how good they convey their messages. Brown \& Levinson (1987), introduce the concept about "face". They define the concept of face in terms of 'wants' and every member wants to be claimed for himself or herself. Moreover, Brown \& Levinson (1987), divided "face" into positive and negative face. The concept of positive face is "the want of every member that his wants be desirable to at least some others executors", or alternately, "the positive consistent self-image claimed by interactions" While, Negative face was defined as "the want of every 'competent adult member' that his actions be unimpeded by others", i.e. the freedom of action and freedom from imposition". In

\footnotetext{
${ }^{1,2,3}$ Facrulty of Cultural Sciences, Hasanuddin University

ELS Journal on Interdisciplinary Studies in Humanities
} 
short sentences can be said that positive face refers to one's self-esteem, while negative face refers to one's freedom to act.

Based on theory above, positive face and negative face are the basic aspects of 'wants' in social interaction and politeness form of utterances are needed to save every member's face. Hidalgo (2000), said that based on discourse approach, negation tends to focus on the relation between negative utterance and corresponding affirmative which is used to deny something. So, it gives influence to the politeness form of expression when using negation.

Negation has the meaning as the way to say something is not the case. It can be formed in negative form. Negation can happen in a number of ways, most commonly, when we use a negative word such as no, not, never, none, nobody, etc. The most common negative words are no and not. So, it against to someone act or speech.

Negation itself is a face threatening act in some situations when someone wants to deny something or someone. The speaker needs to express negation's utterances in polite way to save the face of each through the use of strategies such as transferred negation. Based on this fact the writer is interested in finding kinds of negation expression in Buginese and American speaker, knowing whether the polite form of negation's expression, and how polite negation's expression used by English and Buginese speaker's depends on the form of politeness strategy they choose in speech.

In negation, one way to indicate the politeness of speech is the use of Face Saving Acts (FSA) the opposite of Face Threatening Acts (FTA). FSA is the concept of politeness which is use by the speaker to convey what does he or she 'wants' by reducing the threatening of hearer's face. Negation must obey and apply FSA to save someone's face and to make polite utterance. Based on Miestamo (2007), the standard negation structures found in the world's languages may be divided into symmetric and asymmetric negation, according to whether or not there are structural differences between affirmatives and negatives in addition to the presence of negative markers.

Based on the social situation, there are six configurations based on Yassi (2011), the first configuration is deference in kinship, then deference without kinship, intimate in kinship, intimate without kinship, and the last configuration is hierarchy in kinship.

There have been some researchers studied about the Politeness strategies. The first, Tawalbeh \& Al-Oqaily (2012), conducted a study on in-directness and politeness in American English and Saudi Arabic Request: A Cross Culture Comparison. They found that conventional indirectness was the most prevailing strategy employed by the American sample. On the other hand, the Saudi sample varied their request strategies depending on the social variables of power and distance. The second, Aziz (2014), explained about The Socio-Pragmatic Strategy of Politeness Request in Makassar Culture. She found that Makassarese speakers with different social status have different characteristics and frequency of exchange in interaction between each other. The third, Agus (2013), conducted a research entitled Bentuk Kesantunan Linguistik dan strategi Pertuturan Wanita dan Pria etnis Bugis. This research reveals that female speakers are more polite than the male ones due to differences in the use of linguistic politeness and utterance strategies among them. The woman speakers frequently use linguistics markers, expressing her idea indirectly or implicitly and prefer negative politeness strategy. Meanwhile, the male speakers tend to use less linguistic markers, prefer to speak frankly, and dominantly choose positive politeness strategy. Fuli \& Shuang (2015), wrote a research entitled A Survey of Acquisition of Transferred Negation of English Syntax With Reference to Senior High School TEFL in Mainland China. This study investigates the learning situation of senior high school students in mainland China about acquisition of transferred negation of English sentence structure. The last, Tamra (2016), in her research entitled "The politeness strategies on offer refusals performed by Buginese and American people". She cited that different rule in both languages, in Bone, people tend to use expression "iye" (yes) in refusing something while in America directly say "no". 
Many previous studies explained about politeness strategies in general or in specific term, but there is still few research before investigate about politeness strategies on negation used by Buginese people. Therefore, this research is aimed at finding out the politeness strategies of American and Buginese people in using negation.

\section{Method}

The design of this research is Qualitative Descriptive. Based on Sugiyono (2009), qualitative research is a method that focus on natural data and human as the main tool in doing research. This method applied in this research for some reasons. The first, the data were observed qualitatively from Buginese Bone and American people, because the data were collected in the form of sentences or words rather than number. The second, it was explained descriptively. So, it is called Qualitative method because the data and analysis of data is qualitative in nature.

Data were collected from field and library research. The data are recordings of everyday speech of Buginese people and for each society, Buginese and English data were collected through DCT.

In collecting data, the researcher employed some methods. Firstly, the data were taken from Buginese Bone people and the researcher used direct observation by recording the conversation then taking note and interviewing. Secondly, both data were taken from DCT (Discourse Completion Test). According to Leech (2014), he explained that DCT (Discourse Completion Test) is the most prevalent methods in collecting data. It was taken from both objects.

This research used qualitative method in analyzing data. The data in Buginese were gathered by recording, note taking, and describing. After collecting from recording, the data have been transcribed into written form. Remain data were collected through DCT. English data were collected by DCT. Then, the data were selected which are related to negation expression. Next, the data were analyzed qualitatively. Qualitative method described the fact or phenomena of the data. Finally, the writer classified the utterances or sentences from the data by using face and politeness theory of Brown and Levinson, and analyzed them by describing language phenomena on the data to answer all the questions proposed in this research.

\section{Findings}

The findings elaborate the representation of data in some social situations that display what strategies that Buginese and American people use when making negation.

\subsection{What the strategies is Carried Out}

From data below the answers of $B$ are the data that will be discussed in this study. The FTA of both languages involves three factors are Power (P), Distance (D), and Kinship (K).

\section{Datum 1.}

Solidarity politeness strategy in non-kin context (-P, -D, -K). The speaker is male and older than the hearer. This is an interaction between two colleagues.

\section{Buginese}

A: "Silongekka' diolo silo' lao di pasaē' melli pappanrē bale". (Can you accompany me to go the market? I want to buy fish food)

B: “Ta'ddampengengkka' ndi dē' udapi'l pa' èlo'ka' lao mangesso”. (I am sorry ndi' (young bro/sis), I can't go because I want to dry my rice)

\section{English}

"You thought the movie was great, huh? I didn't really enjoy it that much. I guess to each their own".

\section{Datum 2.}


Solidarity politeness strategy in non-kin context (-P, $-D,-K)$. The speaker is female and older than the hearer. This is an interaction between two colleagues.

\section{Buginese}

A: Magello sedding dianrē di beppa barongkona na diwenni I Beccē' di. Macenni upoji iya' pa' pakanrrē cenningnga iya'. (I ate Becce's cake yesterday. It was sweet and I like it.)

B: Magello' ga? lya' dē' to se'dding (Was it good? I don't think so)

\section{English}

“Isn't it interesting how different we all are? I didn't find the movie very funny".

\section{Datum 3.}

Solidarity politeness strategy in non-kin context $(-P,-D,-K)$. The speaker is male and younger than the hearer. This is an interaction between two colleagues.

\section{Buginese}

A: Talao di bolana Aji Beccē' manrē barobbo'. (Let's go eat to Aji Becce house?)

B: Idi' na daēng, pa messo' mupa' se'dding hē. (You can go there because I am still full now)

\section{English}

"That's good you liked you dessert, mine wasn't as good as I expected".

\section{Datum 4.}

Solidarity politeness strategy in non-kin context $(-P,-D,-K)$. The speaker is female younger than the hearer. This is an interaction between two colleagues.

\section{Buginese}

A: Arēnna' diolo silo' tanengeng asēta' apa' maēga uwita. Dē' to gaga pura millaui ga'? (Could you give me you rice seed? I saw you have much.)

B: A'dampengengngkka', engkani tau pura millaui. (I am sorry, someone has asked about it)

\section{English}

"Really!! I didn't like it that much. It was too sweet".

\section{Datum 5.}

Social situation: Solidarity politeness strategy in kin context $(-P,-D,+K)$. The speaker is male older than the hearer. This is an interaction between two siblings.

\section{Buginese}

A: Daēng talao mattēppo' galung di cē'ddēna sēpeē'? (Let's go to stem the water in the rice fields)

B: Laoni matu' diolo ndi', pa' engka wē' masēke' ēlo' ujama. (You can go ahead bro because I am in hurry to do something)

\section{English}

"I'm sorry I can't help you. I don't really know the answer/ how to do it".

\section{Datum 6.}

Solidarity politeness strategy in kin context $(-P,-D,+K)$. The speaker is female and older than the hearer. This is an interaction between two siblings.

\section{Buginese}

A: Daēng talao mattēppo' galung di cē'ddēna sēpeē'? (Let's go to stem the water in the rice fields) 
B: Lao diolono ndi, paimengpi iya' ulao. (You can go first, I will go next time)

\section{English}

"I'm not sure what your teacher expects. Maybe you should call a friend to help you".

\section{Datum 7.}

Solidarity politeness strategy in kin context $(-P,-D,+K)$. The speaker is male and younger than the hearer. This is an interaction between two siblings.

\section{Buginese}

A: Kanrē-kanrēnna ni kapang kalukuē di cē'ddēna bola galungngē di. Talao mala yaro kaluku? (Maybe the coconut treeclose to the rice fields have already meaty. Would you like to go to take it?)

B: Dē' kullē manrē kaluku lolo pa masemmeng-semmengkka'. (Dē' kullē manrē kaluku lolo pa masemmeng-semmengkka')

\section{English}

"I think we could save some money by staying at my friend's house rather than staying at a hotel. What do you think?"

\section{Datum 8.}

Solidarity politeness strategy in kin context $(-P,-D,+K)$. The speaker is female and younger than the hearer. This is an interaction between two siblings.

\section{Buginese}

A: Kanrē-kanrēnna ni kapang kalukuē di cē'ddēna bola galungngē di. Talao mala yaro kaluku? (Maybe the coconut treeclose to the rice fields have already meaty. Would you like to go to take it?)

B: Idi'na daēng lao malai (Can you go to take it?)

\section{English}

"I think we should consider staying at so and so's house. They have invited us. It will really save us a lot of money and I think it will be fun too. What do you think?"

\section{Datum 9.}

Deference politeness strategy in non-kin context $(-P,+D,-K)$. The speaker is male and older than the hearer. This is an interaction between two strangers.

\section{Buginese}

A: Maēlo'kki' manrē bēppa? (Would you like to eat cake?)

B: Iyē' ba mēnrē' tekanakku' ko manrēka' bēppa. (Yes, I will take blood pressure if I eat cake)

\section{English}

"May I suggest another brand? In case you need service, that brand is not easy to get service in this town"

\section{Datum 10.}

Deference politeness strategy in non-kin context $(-P,+D,-K)$. The speaker is female and older than the hearer. This is an interaction between two strangers.

\section{Buginese}



A: Maēlo'kki' manrē bēppa? (Would you like to eat cake?)
B: lyē'ta anrē ni. (Yes, you can eat it)

\section{English}

"What is it that you like about the painting? I really like this one".

\section{Datum 11.}

Deference politeness strategy in non-kin context $(-P,+D,-K)$. The speaker is male and younger than the hearer. This is an interaction between two strangers.

\section{Buginese}

A: Naēraki' lēppang di bolana, apa' sipangngotoki' pole di Bone kota. Makkedani "dioloka' pale ia no' di. Lēppakki' mai di bolaē ndi!". (You are in the way from Bone city to your village by public transportation. Someone who sits beside you offer you to stop by to her house. So, what would you say to her/him?)

B: Iyē' ba'paēmppi daēng pa' macawē' toni bolaē. (Ok, l'll stop by next time because my house is near from here).

\section{English}

"You are interested in that new phone? One possible downside of that phone is that there is no service center here".

\section{Datum 12.}

Deference politeness strategy in non-kin context $(-P,+D,-K)$. The speaker is female and younger than the hearer. This is an interaction between two strangers.

\section{Buginese}

A: Naēraki' lēppang di bolana, apa' sipangngotoki' pole di Bone kota. Makkedani "dioloka' pale ia no' di. Lēppakki' mai di bolaē ndi!". (You are in the way from Bone city to your village by public transportation. Someone who sits beside you offer you to stop by to her house. So, what would you say to her/him?)

B: Iyē', terima kasih. (Yes, thank you).

\section{English}

"I understand that the service available here does not support that phone. Have you considered any other models?"

\section{Datum 13.}

Deference politeness strategy in kin context $(-P,+D,+K)$. The speaker is male and older than the hearer. This is an interaction between two distance families.

\section{Buginese}

A: Maittasiki' nappa sirintu' di'. Talao pale di bolaē sappo jokka-jokka. (hey, long time no see. Would you like to go to my house?)

B: Paēmeppi ndi' pa' sibu'kka se'dding. (I will stop by next time because I am busy now).

\section{English}

"I'm sorry, I don't know where that is. Sorry I couldn't help you."

\section{Datum 14.}


Deference politeness strategy in kin context $(-P,+D,+K)$. The speaker is female and older than the hearer. This is an interaction between two distance families.

\section{Buginese}

A: Maittasiki' nappa sirintu' di'. Talao pale di bolaē sappo jokka-jokka. (hey, long time no see. Would you like to go to my house?)

B: Iyē' manupi pa maēga jamakku'. (Yes, l'll stop by next time because I have many things to do).

\section{English}

"Sorry, I don't know that address, but I bet I can find it on my phone."

\section{Datum 15.}

Deference politeness strategy in kin context $(-P,+D,+K)$. The speaker is male and younger than the hearer. This is an interaction between two distance families.

\section{Buginese}

A: Diullē ga mēbburaka' dapo' pappada yaro diē'bburengngē' indo'ta? (Can you make a traditional stove for me seems like your mother's stove?)

B: Siseng sangadipi palē' daēng, pa engka to maēlo' tona ujama sangadi. (l'll make it for you two days later, because I also want to do something at the same time)

\section{English}

"I have a dentist who I really like. He is close by and does great work. Would you be interested using him?"

\section{Datum 16.}

Deference politeness strategy in kin context $(-P,+D,+K)$. The speaker is female and younger than the hearer. This is an interaction between two distance families.

\section{Buginese}

A: Gello' pa uwita oto ta' oto baru kapang di. (I really like your car. Is it a new car?)

B: Tania moo oto baru', oto maitta na. (It is not a new car, it is an old car)

\section{English}

"Sorry, but I don't live around here and do not know where it is. Maybe you should ask a shop keeper?"

\section{Datum 17.}

Hierarchical politeness strategy in non-kin context. $(+P,+D,-K)$. The speaker is male and older than the hearer. This is an interaction between an Employee and an Employer.

\section{Buginese}

A: A: Engka ki' di kantoro ē', mattengngangngi' jamai jamatta'. Labei' ponggawata'. Na olli'ki' llao manrē di saliweng. Jaji aga dibaliangngi? (You are doing your work and your boss offer you take a lunch. What would you say to him?)

B: Ta'dampengengkka ndi', Jokkani riolo dē pa na pura jamakku'. (I am sorry, you can go ahead because I haven't finished my work)

\section{English}

"You are interested in investing in that company? I've heard they are having some trouble. They might not be a safe investment". 


\section{Datum 18.}

Social situation: Hierarchical politeness strategy in non-kin context. $(+P,+D,-K)$. The speaker is female and older than the hearer. This is an interaction between an Employee and an Employer.

\section{Buginese}

A: Engka ki' di kantoro ē', mattengngangngi' jamai jamatta'. Labei' ponggawata'. Na olli'ki' llao manrē di saliweng. Jaji aga dibaliangngi? (You are doing your work and your boss offer you take a lunch. What would you say to him?)

B: A'dampengengkka' pa' lo'ka dolo' pappurai jamakku'. Laoni' madiolo, matu'pi ulokka ko purani jamakku'. (I am sorry because I have to finish this work, I'll follow you later. You can go ahead.)

\section{English}

"I have heard the following about that company. Have you heard this?"

\section{Datum 19.}

Social situation: Hierarchical politeness strategy in non-kin context. $(+P,+D,-K)$. The speaker is male and younger than the hearer. This is an interaction between an Employee and an Employer.

\section{Buginese}

A: Lēpppangngi ponggawata' di bolata'. Engka ēlo' na ala. Wettunna èlo' lisu na olli'ki lao bolana makkeda ni. "Talo mai di bolaē jokka-jokka". (Your boss is in your house now. He wants to take something. When he wants to go home. He offers you to come to his house.)

B: lyē' ba daēng, engka muto tu wettu u lēppang di bolata. (Yes of course, I'll stop by to your house next time)

\section{English}

"What do you like about that place? Unfortunately it is pretty far from public transportation. Have you considered this other place?"

\section{Datum 20.}

Social situation: Hierarchical politeness strategy in non-kin context. $(+P,+D,-K)$. The speaker is female and younger than the hearer. This is an interaction between an Employee and an Employer.

\section{Buginese}

A: Lēpppangngi ponggawata' di bolata'. Engka ēlo' na ala. Wettunna ēlo' lisu na olli'ki lao bolana makkeda ni. "Talo mai di bolaē jokka-jokka". (Your boss is in your house now. He wants to take something. When he wants to go home. He offers you to come to his house.)

B: lyē' puang, paimeng pi ulao. (Yes, sir. l'll go next time)

\section{English}

"That location might not be convenient for a lot of other employees because it's far from public transportation."

\section{Datum 21.}

Social situation: Hierarchical politeness strategy in non-kin context. $(+P,+D,-K)$. The speaker is male and older than the hearer. This is an interaction between an Employer and an Employee.

\section{Buginese}

A: Engka pa'jamata' maēlo' mappa'botting amurē na. Na olli'ki', nē idi dē'diullēi llao apa' maēlo'ki' llao di kampongtta' mitai indo'tai. Jaji agana di podangngi pa'jamata'? (Your employee wants to 
make a wedding party. She invites you to attend in that wedding. What would you say to him/her because you have to visit your mother in the village?)

B: Yè' dē bangsa èlo'ku' llao ndi, nē' malasa toi tomatoaē. (I really want to go there but I have to go visit my parent because they sick).

\section{English}

"I don't know that research is necessary at this point. I think we have enough information to make a decision."

\section{Datum 22.}

Social situation: Hierarchical politeness strategy in non-kin context. $(+P,+D,-K)$. The speaker is female and older than the hearer. This is an interaction between an Employer and an Employee.

\section{Buginese}

A: Engka pa'jamata' maēlo' mappa'botting amurē na. Na olli'ki', nē idi dē'diullēi llao apa' maēlo'ki' Ilao di kampongtta' mitai indo'tai. Jaji agana di podangngi pa'jamata'? (Your employee wants to make a wedding party. She invites you to attend in that wedding. What would you say to him/her because you have to visit your mother in the village?)

B: A'dampengengka' ndi', dē' ullēi jokka bottinna' amurēta' apa'na maēlo'ka lao jokka mitai indo'ku' apa' malasai

\section{English}

"I think we already have all the information we need and should continue on with the project".

\section{Datum 23.}

Social situation: Hierarchical politeness strategy in non-kin context. $(+P,+D,-K)$. The speaker is male and younger than the hearer. This is an interaction between an Employer and an Employee.

\section{Buginese}

A: Bos dē' diēlo' llao yē essoè, sappa bahan bangunang?(Bos would you like to go to buy the material building now?)

B: Dē pa kapang daēng, pa' mēnrē maneng bahang-bahangngē. (I think it will be better if we buy it next time because the price of material is expensive now).

\section{English}

"I don't know that machines are the answer. I think high quality advertising is the way to go".

\section{Datum 24.}

Social situation: Hierarchical politeness strategy in non-kin context. (+Power, +Distance, -Kinship). The speaker is female and younger than the hearer. This is an interaction between an Employer and an Employee.

\section{Buginese}

A: Bos ma'bbaju baru siki' ta ro. (Bos, it seems like you wear a new clothes)

B: Puah dè' to waju laung mua, naèkiya nappai upakē'. (It is not a new clothes, I am just wearing it)

\section{English}

"I think we should opened more time and money in advertising. If we have good advertising the profit will come".

\section{Datum 25.}


Social situation: Hierarchical politeness strategy in kin context. $(+P,-D,+K)$. The speaker is male and younger than the hearer. This is an interaction between Children and Parents.

\section{Buginese}

A: Talao indo' di bolana Aji Baco', na olli'ki' garē' mē'bbu' acara (Mom, let's go to Aji Baco house. She invites us to make a party.)

B: Idi'na na' pa' de'pi gaga andrimmu pole sikolaē. (You can go alone, because your brother has not come home from his school)

\section{English}

"I know you wanted to go to summer camp, but I think there is something else that would be better for you for this summer."

\section{Datum 26.}

Social situation: Hierarchical politeness strategy in kin context. $(+P,-D,+K)$. The speaker is female and younger than the hearer. This is an interaction between Children and Parents.

\section{Buginese}

A: Talao indo' di bolana Aji Baco', na olli'ki' garē' mē'bbu' acara (Mom, let's go to Aji Baco house. She invites us to make a party.)

B: Engka maneppi taue dilao. (We go there if everyone has gathered)

\section{English}

"Maybe you can do the camp the next time, this time I want you to..."

\section{Datum 27.}

Social situation: Hierarchical politeness strategy in kin context. $(+P,-D,+K)$. The speaker is male and older than the hearer. This is an interaction between Parents and Children.

\section{Buginese}

A: Na' mullē ga llao wajarakka gollaku di attang di bola na Ajie? (Son, can you go to pay my sugar in Aji's house?)

B: Cinamppē'pi ma' ujama dolo' PRku pole sikolaē. (I'll do it later mom, because I have to do my homework)

\section{English}

"No mother, I think the housekeeper is not doing as good a job she could. I think she could do a better job at .... . Do you not think so?."

\section{Datum 28.}

Social situation: Hierarchical politeness strategy in kin context. $(+P,-D,+K)$. The speaker is female and older than the hearer. This is an interaction between Parents and Children.

\section{Buginese}

A: Na' mullē ga llao wajarakka gollaku di attang di bola na Ajie? (Son, can you go to pay my sugar in Aji's house?)

B: Matu'pi' ulao, purapa' matinro. (l'll go later after I take a nap)

\section{English}

"She has done certain things well but in these matters (I would name them) she has not done a good job." 


\section{Dsicussion}

This research shows that the politeness strategies of negation form in Buginese and English. In Brown and Levinson's theory claimed that this theory has universal form for the categories of politeness strategies. But, those strategies only show the point of view from European and American's culture. Only both cultures have the orientation of Brown and Levinson's theory because they have the same characteristics. Both culture, notably American culture as this research has performed before that in general apply Positive Politeness in making negation. Positive Politeness means that language is in causal form. In other hand, this theory cannot present all kinds of culture. Asian culture tend to use Negative Politeness, as this research's object, Buginese culture shows that in data 5, 6, 9, 10, 11, 12, 14, 19, and 20 the comparison between Buginese and American's culture in general, Buginese culture applies negative Politeness by saying negation indirectly, while in American's data is positive politeness by showing negation directly. The example from datum 5 is the interaction between two siblings. Buginese applies indirect negation by using honorific address term $n i$ and ndi', promising by saying 'Laoni' Matu' diolo" and giving reason. While, English applies direct negation in negate something. Negative politeness means that polite form of conversation or negative face want achieved through shows of deference, while positive politeness shows the friendliness. In other words, it can be said that those languages use different strategies of politeness in using negation.

The same phenomenon from Hierarchical politeness strategy in non-kin context shows that in data 19 and 20 in Buginese people apply Negative politeness. In this data, the speaker is a employer and younger, so they convey messages in making negation to their employee tend to use Negative Politeness. The speaker uses indirect strategy in negate the employee by saying lyē' ba daēng, engka muto tu wettu u lēppang di bolata' and lyē' puang, paimeng pi ulao. The utterance lyē' ba daēng and lyē' puang means "yes" but the intention of the speaker to deny the speaker by promising and postponing the invitation. The other thing is the use of honorific address term such as daēng and puang. In other side, English use direct negation or making question to negate something. In Buginese culture, they apply the concept of Face Saving Acts in giving suggestion or making negation to their other people. This case can happen in Buginese people because they still keep their culture that is rather hierarchy in their life.

\section{Conclusions}

From the findings and discussion, the researcher draws conclusions that Buginese people tend to use negative politeness when they refuse something or making negation. Based on Buginese culture, people will be seen more polite when they respect and use formal language to the other. The other aspect is honorific address term and politeness marker. They tend to use it to make the conversation become polite, although they have close relationship. While American society, the polite form when someone being friendly to others. Buginese people address term should be giving to the other as a polite form, but for American people it is rarely to be used. The other aspects that influence both languages are social status and social distance or intimacy. The researcher hope there will be next research investigating the issues deeper and more accurate local language notably to compare it to the other language.

\section{References}

Agus N. (2013). Bentuk Kesantunan Linguistik dan Pertuturan Wanita dan Pria Etnis Bugis. Makassar: Hasanuddin University.

Azis R. P. (2014). The Socio-Pragmatic Strategy of Politeness Request in Makassar Culture. Makassar: Hasanuddin University.

Brown P. \& Levinson C. S. (1987). Politeness: Some Universals in Language Use. Cambridge: Cambridge University Press.

Chaer A. \& Agustina L. (2010). Sosilinguistik. Jakarta: Rineka Cipta. 
Fuli L. \& Shuang S. (2015). A Survey of Acquisition of Transferred Negation of English Syntax With Reference to Senior High School TEFL in Mainland China.English Language Teaching; Vol. 8, No. 2; 2015 ISSN 1916-4742 E-ISSN 1916-4750. School of Foreign Languages, Southwest University, Chongqing, China: Canadian Center of Science and Education. Accessed on May 23, 2016. Available from: http://files.eric.ed.gov/fulltext/EJ1075191.pdf

Hidalgo L. (2000). The Pragmatics of Fiction. Greenwood Publishing Group

Leech N. G. (2014). The Pragmatics of Politeness. Oxford: Oxford University Press

Miestamo M. (2007). Negation - An Overview of Typological Research.Language and Linguistics Compass 1/5 (2007): 552-570, 10.1111/j.1749-818x.2007.00026.x. University of Helsinki: Journal Compilation Blackwell Publishing Ltd.

http://linguistics.berkeley.edu/ syntax-circle/syntax-group/spr08/miestamo.pdf

Sugiyono. (2009). Metode Penelitian Kuantitative Kualitative dan R\&D. Ikatan Penerbit Indonesia, Alfabeta: Bandung.

Tamra. (2016). The politeness strategies on offer refusals performed by Buginese and American people. Makassar: Hasanuddin Univesity.

Tawalbeh A. \& Al-Oqaily E. (2012). In-directness and Politeness in American English and Saudi Arabic Requests: A Cross-Cultural Comparison. Saudi Arabia: Umm Al-Qura University. Accessed on Augustus 1, 2016 Available from: www.ccsenet.org/ass

Yassi A. H. (2011). Negative and Affirming a Proposition in Makasserese: Revisiting the Universality of Brown and Levinson Politeness Theory' in F Rahman (ed) Kebahasaan, Sastra dan Pendidikan. Prosiding Seminar Internasional: FIB, Universitas Hasanuddin, Makassar, 10-15 